\title{
HEALTH RISK BEHAVIOUR AMONG UNDERGRADUATES IN A MALAYSIAN PUBLIC UNIVERSITY: A CROSS-SECTIONAL STUDY
}

\author{
Liew HC, Noor Illiati I, Raymond Yii SL, Siti Nadzrah Y, Moy FM \\ Faculty of Medicine, University of Malaya, Kuala Lumpur \\ Correspondence: \\ Liew Hoe Chin \\ 95, Taman Makmur, Off JIn. Tun Dr. Ismail, 70200 Seremban, Negeri Sembilan. \\ E-mail: maximilienliew@hotmail.com
}

\begin{abstract}
INTRODUCTION:

Health-risky behaviours among undergraduates are a course of concern both due to its tendency to be carried towards later adulthood and the emergence of non-communicable diseases at younger age group.
\end{abstract}

\section{METHODS AND MATERIAL:}

A cross-sectional study involving 1622 respondents comprising of students undertaking tertiary education was carried out using self-administered questionnaires. (adapted and translated into Bahasa Malaysia from the CDC Health Risk Behaviour Survey)

\section{RESULTS:}

It is found that $6.9 \%$ of the respondents have had sexual intercourse with the mean age of the first intercourse at 18.6 years. Of those who have had intercourse, $25.9 \%$ did not practice safe sex. The study showed that $7.2 \%$ of the undergraduates who drives have driven after taking alcohol and $19.3 \%$ of the respondents have travelled in a car driven by drunk driver. It is also found that $10.8 \%$ of the respondents tried smoking at a young age of 15 years. One point two percent (1.2\%) of the studied population has also taken recreational drugs previously.

\section{CONCLUSION:}

Health risk behaviours among undergraduates in Malaysia are presently existing issues which poses serious concerns.

Keywords: tertiary students, sexual intercourse, substance abuse, recreational drugs, smoking

\section{Introduction}

Undergraduates undergo a transitional state from being under parental supervision to later full adulthood independence. As undergraduates are at this stage being exposed to new environments, ideas, freedom and companies of friends, there is considerable threat faced by these students resulting in major health and social issues. Both, good and bad habits are easily picked up and tend to be a norm in later adulthood. These contribute to the already alarming morbidity and mortality prevalence of nation's healthcare. Due to the sensitive nature surrounding the taboo topic of sexuality in Malaysia, adolescents in this country lack knowledge, guidance and even health support services that are related to reproductive health. With their limited knowledge about their bodies and their sexuality, adolescents are vulnerable to sexually transmitted infections e.g. HIV/AIDS, unplanned early childbearing and unsafe abortions (1). Another health hazard that is related to adolescence is road traffic accidents (RTAs). With more than 20 million people killed a year due to road accidents, it causes more death than wars and diseases put together (2). In Malaysia, road traffic accidents are among the ten top causes of death in Malaysia. A Malaysian government fact sheet reports that $56.3 \%$ of motorcycle accidents involve adolescent age 16-25 years (3). Undergraduates face increased risk of motor vehicle accidents involvement 
due to driving inexperience and impulsiveness. In the United States, $71 \%$ of all deaths among youth and adults aged 10-24 years result from four causes: motor vehicle crashes (31\%), other unintentional injuries (14\%), homicide $(15 \%)$, and suicide (11\%) (4). Another health problem associated with adolescence in Malaysia in drug abuse. In a study conducted in 2002 , it is shown that $18.5 \%$ of the drug addicts admitted to drug rehabilitation centres in Malaysia age 18-24 years (5). While these problems are very apparent, they are preventable and at present, efforts to reduce the incidences of such problems have been said to be enforced through various social programs. However, we come to question the effectiveness of such programs as the numbers reported may not be reflective of today's society. More so when we disagree to the notion of certain parties that these issues are generally related to adolescence of the lower income group and not of the more metropolitan or educated Malaysian population. We believe that this problem plagues not only of the "less educated" adolescent but affects a large proportion of the students of higher learning, such as college students. However, such data are not available and therefore such a hypothesis cannot be proven or disproven. In this study, we hope to shed some lights on the current situation and trends among tertiary students in the public institution in which this study is carried out.

\section{Methodology}

The study was a university-based cross sectional study carried out in the University of Malaya. Included in the study population were undergraduates studying in the university who either stayed inside or outside the campus. A sample of the study population was undertaken. Undergraduates who were long-distant learners and were doing the courses externally were excluded from the study. A traditional definition of undergraduate is employed, that is a student who has freshly graduated from a preuniversity program. As such, the vast majority of students are between 18-24 years of age.

Considering the design effect and response rate, a total sample size of 1657 undergraduates was calculated based on the lowest prevalence to estimate a predicted prevalence of $5 \%$ (for prevalence of exposure for intercourse) with a precision of $5 \%$ and a confidence level of $95 \%$. The total target population in the year $2007 / 2008$ session was 18018 (6). The sample size was calculated using the program Epilnfo statistical calculator.

The sample was picked following a stratified random sampling method. The sample was stratified to Arts and Science stream according to the nature of their study. Proportional allocation was given to faculties from the Science and Arts streams. The samples from each stream were picked in a random manner so that they equate roughly half of the total sample size. The selected faculties are as follows:
Table 1: Faculties chosen for the study.

\begin{tabular}{clcl}
\hline SCIENCE & ARTS & \\
\hline No. & Name of Faculty & No. & Name of Faculty \\
1 & $\begin{array}{l}\text { Computer Science } \\
\text { and Information } \\
\text { Technology }\end{array}$ & 1 & $\begin{array}{l}\text { Business and } \\
\text { Accountancy }\end{array}$ \\
2 & Dentistry & 2 & Economics \& \\
3 & Science & 3 & Administration \\
4 & Built Environment & 4 & $\begin{array}{l}\text { Malay studies } \\
\text { (Academy) }\end{array}$ \\
\hline
\end{tabular}

Data collection was done using a set of questionnaire. With reference to well-tested and standard questions from many surveys carried out to determine the health risk behaviour among youth and undergraduates, such as the CDC Youth Risk Behaviours Survey Year 2007, a set questionnaire were developed to suit local circumstances and settings. Among the areas which were investigated are as follows:

- Demographic background

- Academic background and nature of studies

- Motor Vehicle Accidents (MVA) and road safety prevention precautions.

- Alcohol abuse and tobacco usage.

- Sexual exposure

The questionnaire consisted of 72 questions. The original questionnaire was conceived in English and subsequently translated into the Malay language to facilitate the vast majority of the participants. In Malaysia, the Malay language is the official and national language and understanding the language was a prerequisite for a Malaysian to enter a public university whereas English was learnt as a second language. The questionnaire was designed to protect the students' identity by not disclosing names to encourage anonymousity and voluntary participation.

A pre-testing was carried out and was done on 4 female and 4 male first year biomedicine students. Biomedicine students were chosen as they are not part of the sample to prevent overlapping.

Data collection from the set of questionnaire was selfadministered at the respective faculties from January to April of the year 2008. Questionnaires were distributed to willing students after their respective lectures or tutorials. The data is cleaned and edited for inconsistencies prior to analysis. Out of a total of 1728 sets of questionnaires collected, 106 sets were discarded because more than half of the questionnaire was incompletely filled. This leaves the study with 1622 sets of usable questionnaires. Data collected was entered and analyzed using the SPSS program. Relevant data analysis was done using a significant level of 0.05 . Due to some missing answers to certain survey questions, the denominator used in percentage computation varies according to the responses 
obtained, which was also termed as valid percentage. The response rate was calculated based on the proportion of questionnaire successfully collected relative to the number distributed.

\section{Results}

Table 2: The sociodemographic background of the participants.

\begin{tabular}{lll}
\hline & FREQUENCY & PERCENTAGE (\%) \\
\hline SEX & & \\
Male & 420 & 26.0 \\
Female & 1194 & 74.0 \\
ETHNIC GROUP & & \\
Malay & 873 & 54.039 .4 \\
Chinese & 636 & 3.8 \\
Indian & 61 & 1.9 \\
Bumiputera & 31 & 0.9 \\
Others & 15 & \\
RELIGION & & \\
Islam & 894 & 55.4 \\
Buddhist & 528 & 32.7 \\
Christian & 114 & 7.1 \\
Hindu & 50 & 3.1 \\
Others & 28 & 1.7 \\
MARITAL STATUS & & \\
Single & 1597 & 98.9 \\
Married & 18 & 1.1 \\
PLACE OF ORIGIN & & \\
Urban & & 58.4 \\
Suburban and Rural & 670 & 41.6 \\
ACCOMODATION & & 66.3 \\
Residential college & 1060 & 9.3 \\
Own house & 149 & 24.4 \\
Rented house or room & 390 & \\
\hline & &
\end{tabular}

The response rate for the study was $94 \%$. Out of the total sample population of 1622 students, $74.0 \%$ was female; a reflection of gender composition in a Malaysian institute of higher learning. The mean age for the sample was 21.3 years $(S D=1.59$, range $=26$ years $)$.

On ethnic distribution, the sample consisted of $54.0 \%$ Malays, 39.4\% Chinese, 3.5\% Indians, 1.9\% Bumiputeras and $0.9 \%$ from ethnic group other than stated. A total of $98.5 \%$ of the undergraduates were unmarried. Almost $68.4 \%$ of the respondents originated from urban areas while the rest of the total respondents were from the suburbs and rural areas. The majority of the participants, $66.3 \%$ stayed in residential colleges. Residential colleges are located inside the campus or within walking distances to the university campus. Other respondents either rent a place outside the university, stayed in their own homes or stay with their relatives'. Approximately $49.1 \%$ of the respondents were in a course which is Science related and the rest were Arts related.

\section{Motor Vehicle Accident}

\section{Car}

From the study, $4.7 \%$ of the respondents claimed that they had been involved in a car accident in the past 6 months. Another $4.7 \%$ of motorcycle riders had involved in an accident in the past 6 months.

Table 3: Road safety behaviours practiced by respondent drivers.

\begin{tabular}{|c|c|c|c|c|c|c|c|c|}
\hline \multirow{3}{*}{$\begin{array}{l}\text { Road safety } \\
\text { behaviour }\end{array}$} & \multicolumn{6}{|c|}{ Yes } & \multirow{3}{*}{$\begin{array}{c}\text { Pearson } \\
\text { Chi- } \\
\text { Square } \\
\text { value }\end{array}$} & \multirow{3}{*}{$\mathrm{p}$-value } \\
\hline & \multicolumn{2}{|c|}{ Male } & \multicolumn{2}{|c|}{ Female } & \multicolumn{2}{|c|}{ Total } & & \\
\hline & $\mathrm{n}$ & $\%$ & $\mathrm{n}$ & $\%$ & $\mathrm{n}$ & $\%$ & & \\
\hline $\begin{array}{l}\text { Have been } \\
\text { involved } \\
\text { in a car } \\
\text { accident } \\
\text { (for the } \\
\text { past } 6 \\
\text { months) }\end{array}$ & 26 & 6.2 & 49 & 4.1 & 76 & 4.7 & 3.053 & $<0.08$ \\
\hline $\begin{array}{l}\text { Have } \\
\text { always used } \\
\text { indicator } \\
\text { when } \\
\text { changing } \\
\text { lanes }\end{array}$ & 345 & 94.8 & 755 & 96.7 & 1100 & 96.1 & 2.324 & 0.127 \\
\hline $\begin{array}{l}\text { Have } \\
\text { always put } \\
\text { on seat belt }\end{array}$ & 292 & 80.7 & 657 & 84.6 & 949 & 83.3 & 2.693 & 0.101 \\
\hline $\begin{array}{l}\text { Have } \\
\text { always } \\
\text { adhere } \\
\text { to speed } \\
\text { limit when } \\
\text { driving }\end{array}$ & 197 & 54.0 & 504 & 64.7 & 701 & 61.3 & 12.050 & $<0.01$ \\
\hline $\begin{array}{l}\text { Been inside } \\
\text { a car driven } \\
\text { by a drunk } \\
\text { driver } \\
\text { before }\end{array}$ & 110 & 27.0 & 194 & 16.6 & 304 & 19.3 & 20.739 & $<0.01$ \\
\hline
\end{tabular}

It is found that $96.1 \%$ of the undergraduates who responded have always used indicator when turning or changing lanes. Asked further about road accidents precautions, $83.3 \%$ of the undergraduates have always put on their seat belts when driving. $24.9 \%$ of Malay respondents, the highest among the ethnic groups admitted that they did not always put on their safe belt when driving. There were no significant association found between the use of safety belts and the rate of accidents for the past 6 months.

Only $61.2 \%$ of the respondents claimed they had always adhered to speed limits when driving. Higher proportion of females $64.7 \%$ adhered to speed limit compared to their male counterparts $54.0 \%$.

The overall percentage of respondents who had been inside a car driven by a drunk driver was reported to be $19.3 \%$; males made up a higher percentage $27.0 \%$ compared to 
female respondents $16.6 \%$. Characteristic of respondents who have driven after the intake of alcohol is shown in Table 4.

It was also found that $7.2 \%$ had driven after intake alcohol before. There are more male students (13.7\%) who seemed to have driven after intake of alcohol compared to their female counterpart (4.2\%). Christians and students who rented their rooms or house also have higher percentage of such practices compared to other groups, $20.0 \%$ and $11.2 \%$ respectively. It do not seem to be related to the nature of study, that is, whether they are take a course related to science or arts.

Table 4: Background characteristics of respondents who drive after intake of alcohol.

\begin{tabular}{|c|c|c|c|c|}
\hline \multirow{2}{*}{$\begin{array}{l}\text { Background } \\
\text { characteristics }\end{array}$} & \multicolumn{2}{|c|}{ Yes } & \multirow{2}{*}{$\begin{array}{l}\text { Pearson Chi- } \\
\text { Square value }\end{array}$} & \multirow{2}{*}{$p$-value } \\
\hline & $\mathrm{n}$ & $\%$ & & \\
\hline \multicolumn{5}{|l|}{ Sex } \\
\hline Male & 50 & 13.7 & \multirow{2}{*}{33.64} & \multirow{2}{*}{$<0.01$} \\
\hline Female & 33 & 4.2 & & \\
\hline \multicolumn{5}{|l|}{ Religion } \\
\hline Islam & 8 & 1.5 & \multirow{4}{*}{63.227} & \multirow{4}{*}{$<0.01$} \\
\hline Buddha & 51 & 10.9 & & \\
\hline Hindu & 1 & 3.1 & & \\
\hline Christian & 18 & 20.0 & & \\
\hline \multicolumn{5}{|l|}{ Ethnicity } \\
\hline Malay & 8 & 1.5 & \multirow{6}{*}{65.84} & \multirow{5}{*}{$<0.01$} \\
\hline Chinese & 66 & 11.9 & & \\
\hline Indian & 2 & 5.0 & & \\
\hline Bumiputera & 6 & 37.5 & & \\
\hline Others & 1 & 11.1 & & \\
\hline \multicolumn{4}{|l|}{ Accomdation } & \\
\hline Residential college & 35 & 5.0 & \multirow{3}{*}{13.41} & \multirow{3}{*}{0.001} \\
\hline Own house & 12 & 9.5 & & \\
\hline Rented house/room & 35 & 11.2 & & \\
\hline \multicolumn{5}{|l|}{ Place of Origin } \\
\hline Urban & 63 & 8.4 & \multirow{2}{*}{4.28} & \multirow{2}{*}{0.04} \\
\hline Suburban & 20 & 5.1 & & \\
\hline \multicolumn{5}{|l|}{ Nature of Study } \\
\hline Science & 43 & 7.0 & \multirow{2}{*}{0.081} & \multirow{2}{*}{0.77} \\
\hline Arts & 40 & 7.4 & & \\
\hline
\end{tabular}

\section{Motorcycle}

When asked about having rode a motorcycle before, $56.4 \%$ has done so, $77.6 \%$ consisted of males and $49.0 \%$ females. Only $89.1 \%$ had always worn helmet when riding in the campus while $89.2 \%$ had done so when riding outside the campus. However, of those who used helmet, only a further breakdown of $89.4 \%$ of the respondents said they had put on their helmet appropriately including buckling up. About $51.3 \%$ reported that they had attempted to wear bright or easily visible shirt when riding at night.

Table 5: Road safety behaviours practiced by respondent motorcyclist.

\begin{tabular}{|c|c|c|c|c|c|c|c|c|}
\hline \multirow{3}{*}{$\begin{array}{l}\text { Road safety } \\
\text { behaviour }\end{array}$} & \multicolumn{6}{|c|}{ Yes } & \multirow{3}{*}{$\begin{array}{l}\text { Pearson } \\
\text { Chi- } \\
\text { Square } \\
\text { value }\end{array}$} & \multirow{3}{*}{$p$-value } \\
\hline & \multicolumn{2}{|c|}{ Male } & \multicolumn{2}{|c|}{ Female } & \multicolumn{2}{|c|}{ Total } & & \\
\hline & $\mathrm{n}$ & $\%$ & $\mathrm{n}$ & $\%$ & $\mathrm{n}$ & $\%$ & & \\
\hline $\begin{array}{l}\text { Have rode a } \\
\text { motorcycle } \\
\text { before }\end{array}$ & 318 & 77.6 & 573 & 49.0 & 891 & 56.4 & 100.9 & $<0.01$ \\
\hline $\begin{array}{l}\text { Have been } \\
\text { involved } \\
\text { in a } \\
\text { motorcycle } \\
\text { accident } \\
\text { (for the } \\
\text { past } 6 \\
\text { months) }\end{array}$ & 40 & 9.5 & 35 & 2.9 & 75 & 4.7 & 30.476 & $<0.01$ \\
\hline $\begin{array}{l}\text { Wears a } \\
\text { helmet } \\
\text { when riding } \\
\text { inside the } \\
\text { campus }\end{array}$ & 303 & 94.7 & 474 & 85.9 & 777 & 89.1 & 16.225 & $<0.01$ \\
\hline $\begin{array}{l}\text { Wears a } \\
\text { helmet } \\
\text { when riding } \\
\text { outside the } \\
\text { campus }\end{array}$ & 298 & 92.8 & 500 & 87.1 & 798 & 89.2 & 6.987 & 0.08 \\
\hline $\begin{array}{l}\text { Wears } \\
\text { bright } \\
\text { coloured } \\
\text { clothes } \\
\text { when riding } \\
\text { at night }\end{array}$ & 154 & 47.2 & 315 & 53.5 & 469 & 51.3 & 3.272 & 0.07 \\
\hline $\begin{array}{l}\text { Buckle up } \\
\text { helmet } \\
\text { correctly }\end{array}$ & 260 & 87.0 & 485 & 90.8 & 745 & 89.4 & 3.034 & 0.08 \\
\hline
\end{tabular}

\section{Tobacco Use}

When asked about tobacco usage, about $10.8 \%$ of the students had smoked before. Based on gender basis, the prevalence of smoking was found to be $26.6 \%$ in males and $5.3 \%$ in females. The mean age of their first try was 15 years overall $(S . D=3.94)$. The mean age for the first try of smoking among male respondents was 14.59 years and 15.78 years among female respondents. At the time the study was carried out, $3.5 \%$ of the respondents were still smoking.

The maximum number of cigarette smoked per day was 20 sticks with the mean of 8 sticks per day. Besides, $94.5 \%$ of the respondents could correctly name at least one of the risks of smoking and $50.3 \%$ of the respondents admitted that they have at least a family member who smoked. $69.8 \%$ of the respondents claimed that they were exposed to cigarette smoke before while in campus. 
Table 6: Characteristics of smokers among the undergraduates.

\begin{tabular}{|c|c|c|c|c|c|c|c|c|}
\hline \multirow{3}{*}{$\begin{array}{l}\text { Smoking } \\
\text { behaviour }\end{array}$} & \multicolumn{6}{|c|}{ Yes } & \multirow{3}{*}{$\begin{array}{l}\text { Pearson } \\
\text { Chi- } \\
\text { Square } \\
\text { value }\end{array}$} & \multirow{3}{*}{$p$-value } \\
\hline & \multicolumn{2}{|c|}{ Male } & \multicolumn{2}{|c|}{ Female } & \multicolumn{2}{|c|}{ Total } & & \\
\hline & $\mathrm{n}$ & $\%$ & $\mathrm{n}$ & $\%$ & $n$ & $\%$ & & \\
\hline $\begin{array}{l}\text { Have tried } \\
\text { smoking } \\
\text { before }\end{array}$ & 111 & 26.6 & 63 & 5.3 & 174 & 10.8 & 145.4 & $<0.01$ \\
\hline $\begin{array}{l}\text { Still } \\
\text { smoking } \\
\text { currently }\end{array}$ & 59 & 53.2 & 18 & 28.6 & 77 & 44.3 & 9.844 & $<0.002$ \\
\hline $\begin{array}{l}\text { Have tried } \\
\text { to quit at } \\
\text { least once } \\
\text { before }\end{array}$ & 54 & 83.1 & 16 & 66.7 & 70 & 78.7 & 2.811 & 0.094 \\
\hline $\begin{array}{l}\text { Mean age } \\
\text { of first puff } \\
\text { (years) }\end{array}$ & \multicolumn{2}{|c|}{$\begin{array}{c}14.88 \\
(\mathrm{SD}=3.79)\end{array}$} & \multicolumn{2}{|c|}{$\begin{array}{c}15.78 \\
(S D=3.65)\end{array}$} & \multicolumn{2}{|c|}{$\begin{array}{c}15.19 \\
(S D=6.71)\end{array}$} & & \\
\hline $\begin{array}{l}\text { Mean } \\
\text { number of } \\
\text { cigarette } \\
\text { smoked in a } \\
\text { day (sticks) }\end{array}$ & \multicolumn{2}{|c|}{$\begin{array}{c}9.10 \\
(S D=6.91)\end{array}$} & \multicolumn{2}{|c|}{$\begin{array}{c}5.88 \\
(S D=4.85)\end{array}$} & \multicolumn{2}{|c|}{$\begin{array}{c}8.64 \\
(S D=6.71)\end{array}$} & & \\
\hline $\begin{array}{l}\text { Knows } \\
\text { the risk of } \\
\text { smoking }\end{array}$ & 107 & 96.4 & 59 & 93.7 & 166 & 95.4 & 0.691 & 0.406 \\
\hline $\begin{array}{l}\text { Exposed to } \\
\text { cigarette } \\
\text { smoke in } \\
\text { campus }\end{array}$ & 88 & 79.3 & 41 & 65.1 & 129 & 74.1 & 4.221 & 0.04 \\
\hline
\end{tabular}

\section{Alcohol Consumption and Sexual exposure}

On alcohol, $21.3 \%(n=345)$ of the respondents had exposure to alcohol. Males comprise $32.9 \%(n=137)$ and females $17.5 \%(n=207)$ of them. However, only $1.5 \%(n=25)$ had drank 3 or more times a week and $79.7 \%(n=14)$ of which are males.

The sexual exposure and practice of safe sex was also included in the study. It showed that $6.9 \%(n=110)$ had experienced sexual intercourse before. The mean age of their first sexual intercourse was 18.6 years $(S . D=2.99$ years) with the mean number of sexual partner of 3 people. The mean age of first intercourse for both males and females were the same with varying standard deviations at 3.13 and 2.88 years for males and females respectively. The proportion of male who had sexual exposure was significantly higher at $15.1 \%(n=62)$ compared to females $3.9 \%(n=46)$.The study found that $25.9 \%$ of the respondents did not practised safe sex. The respondents who took science related courses were more likely to practise safe sex, $82.7 \%(n=43)$ compared to those who took arts related subjects, $67.2 \%(n=43) ; p=0.058$. Of those who practised safe sex, $81.6 \%(n=80)$ used condom as one of their contraception and infection transmission prevention method followed by coitus interrupts $29.6(n=24)$ and oral contraceptive pill intake $22.8 \%(n=18)$.
The study shows that fewer respondents who originated from rural areas practised safe sex compared to their urban counterpart and higher percentage of students had sex if they live further away from the campus.

Table 7: $\quad$ Practice of safe sex by background characteristics.

\begin{tabular}{|c|c|c|c|c|}
\hline \multirow{2}{*}{$\begin{array}{l}\text { Background } \\
\text { characteristics }\end{array}$} & \multicolumn{2}{|c|}{ Yes } & \multirow{2}{*}{$\begin{array}{l}\text { Pearson Chi- } \\
\text { Square } \\
\text { value }\end{array}$} & \multirow[b]{2}{*}{$p$-value } \\
\hline & $\mathrm{n}$ & $\%$ & & \\
\hline $\begin{array}{l}\text { Practise safe sex } \\
\text { (condom and/or } \\
\text { oral contraceptives) }\end{array}$ & 86 & 74.1 & & - \\
\hline \multicolumn{5}{|l|}{ Place of origin } \\
\hline Urban & 57 & 82.6 & 6.373 & $<0.05$ \\
\hline Rural & 29 & 61.7 & & \\
\hline \multicolumn{5}{|l|}{ Accommodation } \\
\hline Residential college & 54 & 5.2 & & \\
\hline Own house & 15 & 10.2 & 5.461 & 0.07 \\
\hline Rented house/room & 41 & 10.7 & & \\
\hline \multicolumn{5}{|l|}{ Alcohol } \\
\hline $\begin{array}{l}\text { Have consumed } \\
\text { alcohol before }\end{array}$ & 46 & 54.8 & 1.156 & 0.282 \\
\hline $\begin{array}{l}\text { Never consumed } \\
\text { alcohol before }\end{array}$ & 38 & 45.2 & & \\
\hline
\end{tabular}

\section{Association with stress level}

The respondents of the survey was also asked to rate their own stress level. The scale of stress experienced is a numerical scale ranging from 1 to 5 : 1 being the least stressed; 3 being moderately stressed; and 5 being the highly stressful.

Higher percentages of those who are more stress are exposed to health risk behaviours.

\section{Discussion}

The sample size of the population was chosen based on the predicted prevalence of sexual exposure of $5 \%$. The value of $5 \%$ was picked as an underestimate to the prevalence of sexual exposure found in younger participants in Malaysia which was at $5.4 \%(1)$.

There was a higher compliance of safety belt usage among undergraduates where $83.3 \%$ admitted to have always put on their safety belts compared to the general public where only $76.6 \%$ were seen to have put on their seat belts (7). This result is consistent to the same finding that seat belt compliance was positively associated with educational level, level of enforcement and location as University of Malaya is a public university located at the heart of the capital. As a comparison, the general public of Jakarta 
Table 8: Association of stress level and a few health risk behaviour.

\begin{tabular}{|c|c|c|c|c|}
\hline Stress level & $\begin{array}{c}1 \text { to } 3: \\
\text { Least stressed to } \\
\text { moderatedly stressed } \\
{[\mathrm{N}(\%)]}\end{array}$ & $\begin{array}{c}4 \text { and 5: } \\
\text { Between moderately } \\
\text { stressed and highly } \\
\text { stressful }[\mathrm{N}(\%)]\end{array}$ & $\begin{array}{c}\text { Person Chi- } \\
\text { Square } \\
\text { Value }\end{array}$ & $\mathrm{p}$-values \\
\hline Driven after the intake of alcohol & $53(6.0)$ & $30(11.2)$ & 8.252 & 0.004 \\
\hline $\begin{array}{l}\text { Involved in a car accident in the past } \\
6 \text { months }\end{array}$ & $50(4.0)$ & $26(7.6)$ & 8.351 & 0.005 \\
\hline Ever smoked before & $121(9.5)$ & $53(15.6)$ & 10.285 & 0.001 \\
\hline Have ever consumed alcohol & $243(19.2)$ & $102(30.1)$ & 18.807 & $<0.010$ \\
\hline Had sexual intercourse before & $77(6.1)$ & $33(9.9)$ & 5.783 & 0.016 \\
\hline
\end{tabular}

had higher compliance to seat belt use where up to $78 \%$ were reported to be using seatbelt (8). However, no data on the percentage of seatbelt use was found for their undergraduates.

The incidence where an undergraduate has been in the car with a drunk driver was considerably lower compared to western countries. The percentage of lifetime exposure found in this study was $19.3 \%$ compared to over $28.5 \%$ in the United Stated although the study was done over a much shorter time period of only 30 days (3). In the United States, $29.0 \%$ of respondents of a study involving college students were reported to have driven after intake of any amount of alcohol. A lower percentage is seen in this study where $7.2 \%$ of the respondents in this study admitted to have done it. Although there were few published articles reporting on drunk driving specifically among tertiary students regionally, the percentage of drunk driving is lower compared to the general population reported elsewhere amongst European countries. Locally, it is estimated that $30 \%$ of road accidents nationwide are caused by drinking and driving (9). A national study published in the year 2004 found that road traffic accidents is the main contributed for Disability-Adjusted Life Years (DALYs) among males aged 15 to 29 years old amounting to 70,469 or $24.9 \%$ of the total. It is the third main cause of DALYS among females of the same age with 9549 or $6.8 \%$ of the total. One of the contributing factors to the overall lower prevalence of driving under the influence of alcohol was the composition of the sample population and therefore the population in this area. Malaysia is made up mainly of Muslims who are prohibited from taking alcoholic drinks. However, the prevalence of driving after the intake of alcohol among other races was higher.

Motorcycle riding is a convenient and relatively cheap mode of transportation. It is especially popular among university student. From this study, $56.5 \%$ of the undergraduates had ridden a motorcycle before at some point of their life. However, riding a motorcycle also bears a high risk of injury, especially among youth.

The use of helmet was one of the most studied safety behaviours among motorcyclist. It is found in this study that the rate of unprotected motorcycle riding in terms of safety helmet usage were $11 \%$ when riding inside the campus and
$10.8 \%$ when riding outside the campus. These figures were low compared to the rate of unprotected riding obtained from the general public in Malaysia, at a value of $24.2 \%$. As a comparison to Indonesia, where helmet use is also legally mandatory, the percentage of motorcyclists who does not use helmet among the general public there is similar to the percentage found among the undergraduates here at $11 \%$ (10). Nevertheless, helmet usage here is much higher compared to less developed countries such as Pakistan where only $56.3 \%$ were reported to wear helmets (11).

Moreover, among those who wear a helmet, it is often improperly worn. About $10.5 \%$ of those who wore helmet put them on improperly in this study compared to the general Malaysian population at the figure of $21.4 \%$ (12). $10.8 \%(n=174)$ of the undergraduates had ever smoked before. $26.6 \%$ were males and $5.3 \%$ were females. The percentage found in this study was lower compared to the general population of the age group 20-24 years which was at $26.4 \%$ for those who have ever smoked and $24.7 \%$ for those who were currently smoking for the same age group. The percentage found in this study was also lower compared to the percentage of smokers in the general population who have attained tertiary education which was at $14.2 \%(13)$.

Mean age of the respondentwhen thet first tried smoking was 15 years. This age was considerably younger if it was to be compared with other countries. In Indonesia, the average age of first puff was 17.4 years in the year 2004 (14). The maximum number of cigarette smoked per day was 20 sticks with the mean of 7 sticks per day which was also lower compared to the general population at 12.1 sticks per day (13).

The prevalence of sexual exposure found from this study was $6.9 \%$ overall; $15.1 \%$ among males and $3.9 \%$ among females. These figures were still lower than other Asian countries such as Korea which reports $23 \%$ of males and $10 \%$ of female university students had sexual experience (15). Another local study done to determine the prevalence of sexual prevalence among 4500 secondary school students found the prevalence to be $5.4 \%$ (1). The percentage adolescent does not use any contraception among undergraduates (25.9\%) was also lower compared to a neighbouring country which reports $48 \%$ of unmarried 
females never use any contraception (16). Despite this, a lack of safe sex practise in Malaysia was still a worrying trend. This is in view of the number of women and young girls being infected with HIV had risen from $4 \%$ in 1995 to $18 \%$ in 2009 (17). It was also stated that $25 \%$ to $40 \%$ of them had contracted the disease from their husbands or boyfriends. The Malaysian government recently announced that sex education will be implemented nationwide after the response to the pilot project were encouraging in providing knowledge and awareness in sexuality, pregnancy prevention, unsafe abortion, abandoned babies and sexually-transmitted disease. The mean age of first sexual intercourse in this study was $\mathbf{1 8 . 6 4}$ years for both males and females, compared to a developmentally equivalent South East Asian country, the Philippines which were 18 years for males and 18.3 years for females (18). However, it was lower that national data which reported 24.8 years and 22.8 years in males and females respectively among the general population (13).

The study which was carried out presented with several limitations. First, the data collected may not truly reflect the undergraduates as those who participated in the study were voluntary. Secondly, there may be under or overreporting as in many self-administered questionnaires. Although, steps were taken to minimize reporting error, under-reporting or over-reporting cannot be ruled out. Steps to minimize reporting error included ensuring anonymity through steps such as recruiting participants on voluntary basis, having no questions on the first and last page of the questionnaire, allowing as much time as needed for questionnaire completion and collecting the completed questionnaire as soon as completed. One presenting problem in carrying out the study is that not all the students finish the questionnaires at the same time, reducing privacy towards the end of the session. Due to lack of facilities and expected reduction in the turn out, the session could be carried out in separate cubicles. Cigarette smoking was the only measure of nicotine intake assessed in this study. Other forms of tobacco use (skin patches) were not measured in this study albeit not popular.

On the other hand, the study is only conducted in one public university in Kuala Lumpur; data collected from the study may not reflect the general situation in the whole country as different campuses may have different student make-up and local settings. This study may not represent the true situation in private institute of higher learning due to differences in student composition, rules and other local settings.

\section{Conclusion and Recommendation}

Our study demonstrates that undergraduates take unnecessary risks on the road as reflected by the low practices of road safety behaviour. Safety belt usage was still considerably low even among university students despite the fact that a law has been put in place for many years. Driving consuming alcohol was not as rampant as it was in the West but still pose a dangerous practice. Data on sexual behaviour from around the Asian region was not readily available but from places where it was available, the prevalence of university students engaging in sexual activities was much higher than in Malaysia than had been anticipated.

\section{Acknowledgement}

The authors would like to express their thanks for all the participants of the study and to the university for granting permission to carry out the study.

\section{References}

1. Lee L K, Chen P C Y, Lee K K, Kaur J. Premarital sexual intercourse among adolescents in Malaysia: a crosssectional Malaysian school survey. Singapore Med J 2006; 47(6): 476-81.

2. Azmani W, Mohamed RA, Aziz Al, Hashim M. Pattern of Road Traffic Accident in Kelantan. NCD Malaysia 2005; 4(4).

3. Ministry of Health. Online Guidelines to Road Safety. Putrajaya: Ministry of Health. Available on www. infosihat.gov. my/PDF\%20Penyakit/Kemalangan\%20 Jalanraya.pdf. Accessed on July 28, 2008.

4. Eaton DK et al. Youth Risk Behavior Surveillance, United States, 2005. MMWR Surveillance Summaries 2005; 55:1-4.

5. PEMADAM. Fact sheet from drug rehabilitation authority. Kuala Lumpur: PEMADAM. Available at www.pemadam.org. my/cda/m_fakta/fkt_sta_ penagihan.php. Accessed July, 2008.

6. University of Malaya. UM Fact sheet. Kuala Lumpur: University of Malaya. Available at http:// www.um.edu.my/discover_um/um_fact_sheet. php?intPrefLangID=1\&. Accessed January, 2008.

7. Kulanthayan S., Raha A.R., Law T.H., Radin U.R.S. Seat belt use among car users in Malaysia. IATSS RESEARCH 2004; 28(1).

8. Putranto LS et al. Characteristics of Seat belt use in Jakarta. Proceedings of the Eastern Asia Society for Transportation Studies 2005; 5:1963-72.

9. WHO. Global Status Report on Alcohol 2004. Geneva: World Health Organisation; 2004.

10. Conrad $P$ et al. Helmet, injuries and cultural definitions: motorcycle injuries in urban Indonesia. Accid Annal Prev 1996; 2:193-200.

11. Khan I et al. Factors associated with helmet use among motorcycle user in Karachi, Pakistan. Academy of Emergency Medicine 2008; 4:384-7.

12. Kulanthayan et al. Compliance of Proper Safety Helmet Usage In Motorcyclist. Med J Malaysia Mar 2000; 55(1).

13. Institute for Public Health (IPH) 2008. The Third National Health and Morbidity Survey 2006. Ministry of Health, Malaysia.

14. National Socio-Economic Survey. Badan Pusat Statistik, Indonesia; 2004. 
15. Lim, J.K. Sexual Behavior and Contraceptive Use of Korean Young Men, Seoul. Korea Institute for Health and Social Affairs; 1995.

16. Suporn K. Adolescent reproductive health. In: H. M. Wallace \& K.Giri ,editors. Health Care of Women and Children in Developing Countries. Oakland: Third Party Publishing, 1990.
17. Aruna P. More women have HIV. The Star [Malaysia] 25 Nov 2010.

18. Berja CL. Case study, Philippines: communication and advocacy strategies adolescent reproductive and sexual health. Bangkok: UNESCO PROAP,1999; 2:29. 